\title{
RARE PEDIASTRUM SPECIES (CHLOROPHYCEAE) FROM POLISH COASTAL LAKES
}

\author{
JOANNA KOWALSKA, KONRAD WOŁOWSKI \\ Department of Phycology \\ W. Szafer Institute of Botany, Polish Academy of Sciences \\ Lubicz 46, 31-512 Kraków, Poland \\ e-mail: j.kowalska@botany.pl
}

(Received: December 17, 2009. Accepted: February 3, 2010)

\begin{abstract}
An account is given of the occurrence of Pediastrum (Chlorophyceae, Sphaeropleales) in five eutrophic coastal lakes (Jamno, Bukowo, Gardno, Łebsko and Sarbsko) in northern Poland, together with morphological data of the species and more detailed taxonomic and ecological information for three taxa which appear to be rare world wide. These are $P$. musterii, $P$. orientale and P. alternans; the first is recorded for the first time from central Europe. $P$. orientale and $P$. alternans show considerable morphological variability under different environmental conditions, indicating the need for further studies. The studied lakes seem to be especially favourable for Pediastrum, with a total of eight species (15 taxa) in the phytoplankton noted during the summer. However, the relative frequency of the genus in the overall algal communities was low. The most frequent species were $P$. boryanum, $P$. kawraiskyi and $P$. duplex and these were accompanied by cyanobacteria, coccal green algae (Chlorophyceae, Chlorococcales) and diatoms (Bacillariophyceae). All the Pediastrum taxa were documented using LM and SEM.
\end{abstract}

KEY WORDS: Pediastrum, taxonomy, ecology, distribution, coastal lakes.

\section{INTRODUCTION}

Green algae of the genus Pediastrum Meyen (Chlorophyceae, Sphaeropleales; Graham et al. 2009) are often found in phytoplankton of lakes and ponds. They mainly live in fresh-water reservoirs; data from brackish and salty waters are rare (Parra 1979). Of the 24 Pediastrum species, only four, $P$. boryanum, $P$. duplex, $P$. simplex and $P$. tetras, have a really world-wide distribution and generally occur in eutrophic waters (Komárek and Jankovská 2001).

Most Pediastrum species are rare, having geographically restricted distribution or are recorded from only several distant localities. For example, $P$. kawraiskyi is a boreo-alpine species, $P$. musterii has been reported only from Europe (Tell and Mataloni 1990; F. Hindák, pers. comm.), Japan (Komárek and Jankovská 2001) and South America (Tell and Mataloni 1990; Izaguirre and Vinocur 1994; Comas Gonzalez and Perez Bariero 2002), P. alternans has mainly been recorded from northern Europe (Nygaard 1949; Komárek and Jankovská 2001).

Ecology of the rare Pediastrum species and varieties is still not well known (Parra 1979; Komárek and Jankovská 2001). Knowledge on the environmental requirements of these taxa can be useful for determination of trophocity or salinity in not only present-day, but also past water bodies, because Pediastrum is well preserved in lake sediments and found in palynological samples (Jankovská and Komárek 1995; Dupont and Weinelt 1996; Latałowa and Borówka 2006; Sarmaja-Korjonen et al. 2006).

The genus Pediastrum has been little studied in Polish brackish lakes. Strzelecki and Półtorak (1971) noted several Pediastrum taxa in Lake Gardno, while Picińska-Fałtynowicz (1997) and Burchardt et al. (2003) observed Pediastrum in lakes Gardno and Łebsko.

The present studies were undertaken to determine Pediastrum taxa in five eutrophic coastal lakes, Jamno, Bukowo, Gardno, Łebsko and Sarbsko. More detailed information on taxonomy and ecology was obtained for those species previously considered to be rare. All the taxa were documented using LM and SEM.

\section{STUDY AREA}

The material was collected in June 2008 from five coastal lakes in northern Poland: Jamno, Bukowo, Gardno, Łebsko and Sarbsko (Fig. 1), all within the mesoregion Słowińskie Coast (Kondracki 1994). The lakes are located within the administrative boundaries of Pomorskie (Gardno, Łebsko and Sarbsko) and Zachodniopomorskie (Jamno and Bukowo) Provinces. Lakes Gardno and Łebsko are in the Słowiński National Park. 


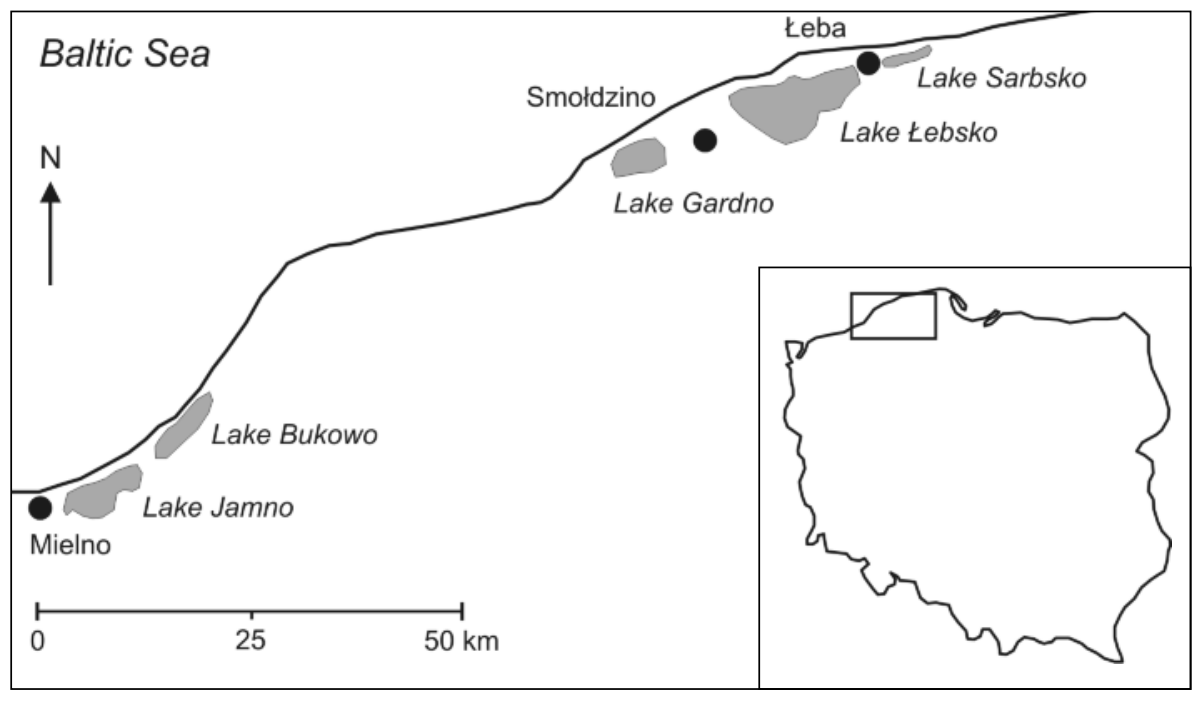

Fig. 1. Location of the investigated coastal lakes in Poland.
The particular conditions for planktonic algae in these lakes include their morphometry and location near the Baltic Sea. They are all characterized by large area and shallow depth (Table 1). The lakes are eutrophic (Filipiak and Raczyński 2000), with vertical mixing of the water favouring access to nutrients such as nitrogen and phosphorus from the bottom. The catchment area supports the presence of coccal green algae (Burchardt et al. 2003). The high phosphate concentration $\left(0.75 \mathrm{mg} \mathrm{L}^{-1} \mathrm{PO}_{4}\right)$ in Lake Jamno was also due in part to municipal sewage released near the sampling place. Starmach (1969) observed a similar phosphate concentration in eutrophic Lake Mikołajskie.

Although these lakes are isolated from the Baltic Sea by narrow sandy banks they are exposed to inputs of salt water, as shown by the high chloride concentrations (Strzelecki and Półtorak 1971; Florczyk et al. 1976). Lakes Bukowo and Łebsko have 800 and $1044 \mathrm{mg} \mathrm{L}^{-1} \mathrm{Cl}$, respectively; both lakes have high conductivity $\left(>1500 \mu \mathrm{S} \mathrm{cm}^{-1}\right)$ and significant differences between total and carbonate hardness (1.7 and $2.2 \mathrm{mmol} \mathrm{L}^{-1} \mathrm{Ca}$, respectively). Lakes Jamno and Gardno are much less influenced by $\mathrm{Cl}$ (Table 1), while Lake Sarbsko is truly freshwater $\left(40 \mathrm{mg} \mathrm{L}^{-1} \mathrm{Cl}, 152 \mu \mathrm{S} \mathrm{cm}^{-}\right.$ 1, total hardness $1.6 \mathrm{mmol} \mathrm{L}^{-1} \mathrm{Ca}$, carbonate hardness 2.0 $\mathrm{mmol} \mathrm{L}^{-1} \mathrm{Ca}$ ). The lake is more influenced by rain and ground waters than salt water from the Baltic Sea (Florczyk et al. 1976).

\section{MATERIAL AND METHODS}

Littoral samples were taken using a plankton net no. 25 . Selected physic-chemical water parameters were measured in field with an Elmetron $\mathrm{pH} /$ conductivity meter CPC-401 equipped with an electrode EPS-1 and a set Aqua Merck Compact Laboratory produced by Merck (Table 1). The material was partly preserved with $2-4 \%$ formaldehyde and partly left living for culturing.

A unialgal culture of $P$. alternans (strain no. 01.160708) was started with a single 32-celled coenobium which was transferred with a micromanipulator Narishige MM 188 into a test tube containing ca. $5 \mathrm{ml}$ of liquid medium composed of equal contents of Knop's medium (Starmach 1963) and Chu's medium (Chu 1942, cited in: Parra 1979). The strain grew in a phytotron at ca. $20^{\circ} \mathrm{C}$ under fluorescent tubes of changing $15 \mathrm{~W} / 2 \times 15 \mathrm{~W}$ intensity with $5 / 19 \mathrm{hr}$ cycle.

The formaldehyde-preserved material and the described strain were examined using light and scanning electron microscopes. Light microscopy (LM) studies were made using a Nikon OPTIPHOT-2 microscope. Micrographs were taken with a PixeLINK PL-A661. For scanning electron microscopy (SEM) the samples were first rinsed with distilled water, laid on cover glasses and air-dried at 30$40^{\circ} \mathrm{C}$. The cover glasses were then affixed to aluminium stubs with double-sided carbon tape. The stubs were coated

TABLE 1. Morphometric parameters (according to Florczyk et al. 1976 ${ }^{1}$; Borówka 2002²; Burchardt et al. 2003 ${ }^{3}$ ) and chemical features of the investigated lakes.

\begin{tabular}{|c|c|c|c|c|c|}
\hline & Jamno $^{1}$ & Bukowo $^{2}$ & Gardno $^{3}$ & Łebsko $^{3}$ & Sarbsko $^{1}$ \\
\hline Position & $\begin{array}{c}54^{\circ} 17^{\prime} \mathrm{N}, \\
16^{\circ} 09^{\prime} \mathrm{E}\end{array}$ & $\begin{array}{c}54^{\circ} 21^{\prime} \mathrm{N} \\
16^{\circ} 17^{\prime} \mathrm{E}\end{array}$ & $\begin{array}{c}53^{\circ} 39^{\prime} \mathrm{N}, \\
17^{\circ} 22^{\prime} \mathrm{E}\end{array}$ & $\begin{array}{c}53^{\circ} 43^{\prime} \mathrm{N}, \\
17^{\circ} 25^{\prime} \mathrm{E}\end{array}$ & $\begin{array}{c}54^{\circ} 45^{\prime} \mathrm{N}, \\
17^{\circ} 40^{\prime} \mathrm{E}\end{array}$ \\
\hline Surface $\left[\mathrm{m}^{2}\right]$ & $224 \times 10^{5}$ & $175 \times 10^{5}$ & $247 \times 10^{5}$ & $714 \times 10^{5}$ & $65 \times 10^{5}$ \\
\hline Max. depth [m] & 3.9 & 2.8 & 2.6 & 6.3 & 3.2 \\
\hline Mean depth $[\mathrm{m}]$ & 1.4 & 1.8 & 1.3 & 1.6 & 1.2 \\
\hline Water temperature $\left[{ }^{\circ} \mathrm{C}\right]$ & 24.6 & 23.6 & 19.8 & 19.5 & 25.0 \\
\hline $\mathrm{pH}$ & 9.6 & 9.3 & 8.9 & 9.3 & 9.4 \\
\hline Conductivity $\left[\mu \mathrm{S} \mathrm{cm}^{-1}\right]$ & 425 & 1540 & 560 & 1740 & 152 \\
\hline Total hardness $\left[\mathrm{mmol} \mathrm{L}^{-1} \mathrm{Ca}^{2+}\right]$ & 2.2 & 4.2 & 2.1 & 5.0 & 1.6 \\
\hline Carbonate hardness $\left[\mathrm{mmol} \mathrm{L}^{-1} \mathrm{Ca}^{2+}\right]$ & 3.2 & 2.5 & 2.2 & 2.8 & 2.0 \\
\hline Nitrate $\mathrm{NO}_{3}^{-}\left[\mathrm{mg} \mathrm{L}^{-1}\right]$ & $<5$ & $<5$ & $<5$ & $<5$ & $<5$ \\
\hline Phosphate $\mathrm{PO}_{4}^{3-}\left[\mathrm{mg} \mathrm{L}^{-1}\right]$ & 0.75 & $<0.15$ & $<0.15$ & $<0.15$ & $<0.15$ \\
\hline $\mathrm{Cl}^{-}\left[\mathrm{mg} \mathrm{L}^{-1}\right]$ & 116 & 800 & 254 & 1044 & 40 \\
\hline
\end{tabular}



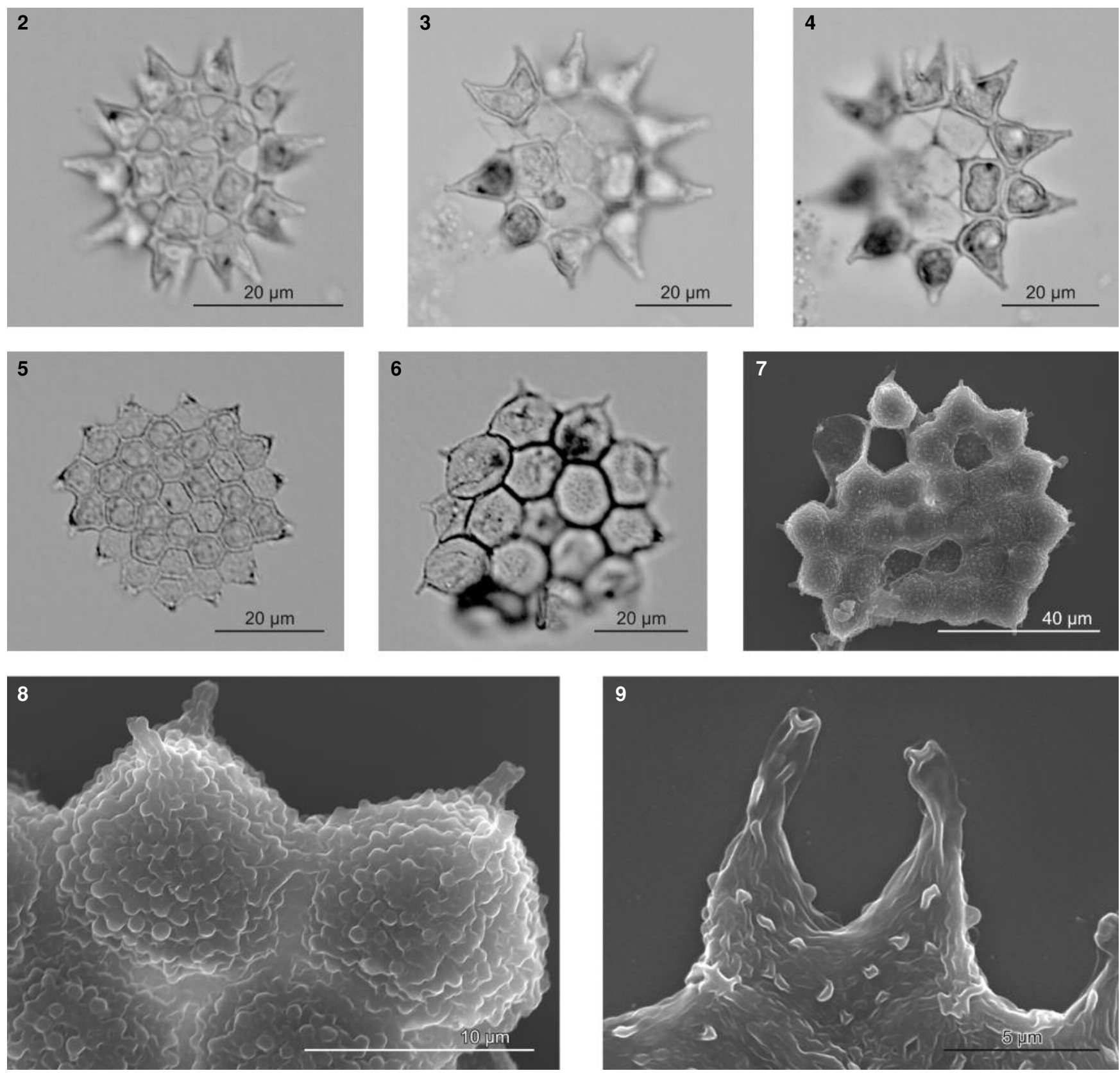

Figs 2-9. Figs. 2-4. P. musterii Tell et Mataloni. Fig 2. A young coenobium (LM). Figs 3-4. An older coenobium in different views (LM). Figs 5-8. Pediastrum orientale Jankovská et Komárek. Fig. 5. A young coenobium (LM). Fig. 6. An empty coenobium with granules on the cell wall surface (LM). Fig. 7. A matured ceonobium (SEM). Fig. 8. Two cells with wrinkled cell wall surface with distinct, irregularly disposed granules (SEM). Fig. 9. A cell of $P$. alternans Nygaard from cultured material with wrinkled cell wall surface and distinct thickenings (SEM).

with carbon using a Cressington sputter-coater and viewed with a Hitachi S-4700 microscope. SEM-micrographs were taken in the Laboratory of Field Emission, Scanning Electron Microscopy and Microanalysis at the Institute of Geological Sciences of the Jagiellonian University, Cracow.

\section{RESULTS}

In the studied lakes 15 Pediastrum taxa were noted (Table 2), with the list present in the sequence used by Komárek and Jankovská (2001). All taxa were documented using LM and SEM (Figs 2-27). More detailed accounts were prepared for the rare species, $P$. musterii, $P$. orientale and $P$. alternans, including notes on taxonomy, distribution and ecology.

\section{$P$. musterii Tell et Mataloni 1990}

(Figs 2-4)

Synonyms: $P$. kawraiskyi Schmidle according to Brook (after Tell and Mataloni 1990); Pediastrum sp. Guarrera et al. (after Tell and Mataloni 1990); P. duplex Meyen var. genuinum Raciborski fo. convergens Raciborski according to Nygaard (after Tell and Mataloni 1990); P. kawraiskyi var. perforatum Akiyama according to Hirose and Yamagishi (after Komárek and Jankovská 2001).

Coenobia 35-54 um diameter, circular in outline, with small perforations, 16-celled. Marginal cells 9-16 $\mu \mathrm{m}$ long, 8-12 $\mu \mathrm{m}$ wide, with two conical lobes situated perpendicular to the plane of coenobium, ended with hyaline processes. The base of marginal cells concave, flat or slightly convex. Inner cells 6-10 $\mu \mathrm{m}$ long, 7-12 $\mu \mathrm{m}$ wide, quadrangular with concave or flat sides. 

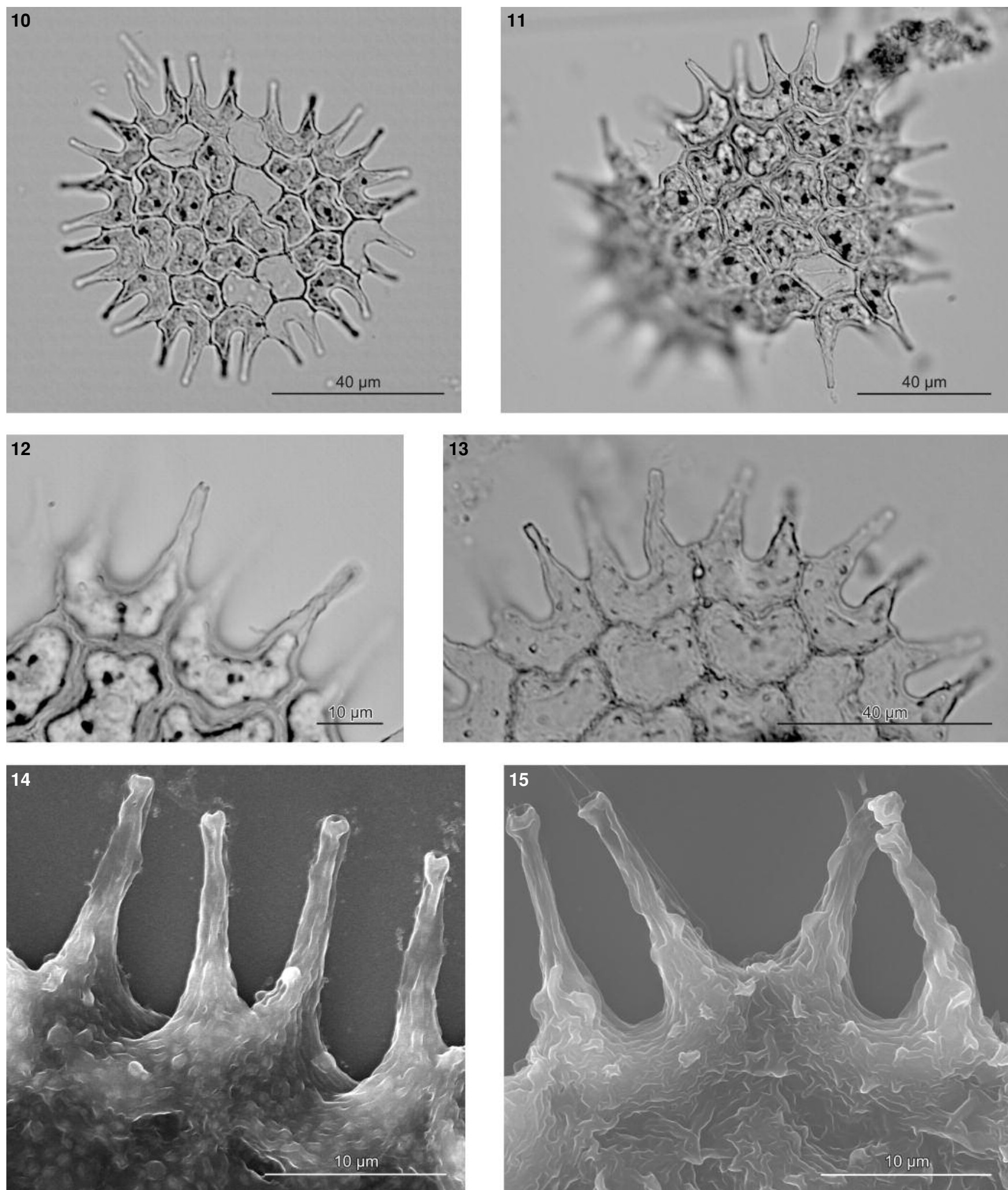

Figs 10-15. P. alternans Nygaard. Fig. 10. A circular coenobium with deep U-shaped incisions and lobes directed obliquely downwards and upwards (LM). Fig. 11. An oval coenobium (LM). Fig. 12. Two filled cells with thickenings of the cell wall surface, undulate adjacent cell walls and lobes margin (LM). Fig. 13. Several empty cells with thickenings of the cell wall surface (LM). Fig. 14. Two cells with finely wrinkled cell wall surface looking like regularly granulated (SEM). Fig. 15. Two cells of another coenobium with distinctly wrinkled cell wall surface (SEM).

\section{Taxonomic notes}

A young coenobium (Fig. 2) from Lake Łebsko had a concave base of marginal cells and concave sides of inner cells, so it is a typical specimen of $P$. musterii. However, a mature coenobium (Figs 3-4) from the same lake had a flat or slightly convex base of marginal cells and flat sides of inner cells, so it is very similar to $P$. patagonicum Tell et Mataloni. The cell wall sculpture was not studied, other taxonomic features indicate that both are $P$. musterii. 
TABLE 2. Pediastrum taxa found in the investigated lakes (* rare species described in text; + present; - absent).

\begin{tabular}{|c|c|c|c|c|c|}
\hline & Jamno & Bukowo & Gardno & Łebsko & Sarbsko \\
\hline *P. musterii Tell et Mataloni (Figs 2-4) & - & - & - & + & - \\
\hline P. kawraiskyi Schmidle (Fig. 16) & + & + & + & + & + \\
\hline *P. orientale (Skuja) Jankovská et Komárek (Figs 5-8) & - & + & + & + & - \\
\hline P. boryanum (Turpin) Meneghini var. boryanum (Fig. 17) & + & + & + & + & + \\
\hline P. boryanum cf. var. cornutum (Raciborski) Sulek (Fig. 18) & - & - & + & - & - \\
\hline P. boryanum var. perforatum (Raciborski) Nitardy (Fig. 19) & + & - & + & - & + \\
\hline P. boryanum var. longicorne Reinsch (Fig. 20) & - & - & + & - & + \\
\hline P. boryanum var. brevicorne A. Braun (Fig. 21) & + & - & + & - & - \\
\hline P. boryanum var. forcipatum (Corda) Chodat (Fig. 22) & + & - & + & + & + \\
\hline P. duplex Meyen var. duplex (Fig. 23) & + & + & + & + & + \\
\hline P. duplex var. gracillimum W. et G. S. West (Fig. 25) & - & + & + & - & + \\
\hline P. duplex var. rugulosum Raciborski (Fig. 27) & - & + & - & + & - \\
\hline *P. alternans Nygaard (Figs 9-15) & + & - & + & + & + \\
\hline P. tetras (Ehrenberg) Ralfs (Fig. 26) & - & + & - & + & + \\
\hline P. biradiatum Meyen (Fig. 24) & - & - & + & - & - \\
\hline
\end{tabular}

\section{Ecology and distribution}

This is the first published information on the occurrence of $P$. musterii in central Europe. The species was sporadically observed in Lake Łebsko. F. Hindák (pers. comm.) has also observed it in the Vistula Lagoon (Poland). It has previously been noted from several distant localities: two lakes in an arid region of Patagonia, Denmark (Tell and Mataloni 1990), meso-eutrophic lakes with potentially high alkalinity near Buenos Aires (Izaguirre and Vinocur 1994), Japan (Komárek and Jankovská 2001) and Merin Lagoon (Brazil-Uruguay; Comas Gonzalez and Perez Bariero 2002). Komárek and Jankowská (2001) suspected that the species occurs sporadically in clear lakes in temperate zones of both hemispheres. However, the present data show that $P$. musterii also occurs in eutrophic and brackish water bodies. Its ecological requirements remain to be studied.

\section{P. orientale (Skuja) Jankovská et Komárek 1995}

(Figs 5-8)

Synonyms: $P$. pearsoni G. S. West var. orientale Skuja 1937; P. integrum Nägeli var. granulatum Raciborski according to Bourrelly (after Komárek and Jankovská 2001); $P$. kawraiskyi Schmidle according to Nielsen and Sørensen 1992; P. kawraiskyi Schmidle according to Sitkowska 1992, Pl. 23, Figs 2, 4-6; Pl. 24, Figs 3-5.

Coenobia 44-74 $\mu \mathrm{m}$ diameter, circular or slightly irregular in outline, without perforations, 16-32-celled. Marginal cells 8-13 $\mu \mathrm{m}$ long, 7-14 $\mu \mathrm{m}$ wide, convex at the outline, without incisions and lobes, with two processes more than four times shorter than the cell diameter, situated in the middle of the outer cell margin, perpendicular to the plane of coenobium, exceptionally processes lacking. Inner cells 7-12 $\mu \mathrm{m}$ long, 6-15 $\mu \mathrm{m}$ wide, irregularly polygonal. Cell wall surface wrinkled with distinct, irregularly disposed granules.

\section{Taxonomic notes}

Jankovská and Komárek (1995) described two different populations of $P$. orientale from fossil material: with short processes; these were also observed in the studied material and by Sitkowska (1992); with long processes; these were also noted by Pasztaleniec and Poniewozik (2004: p. 45, Figs 20-24). Jankovská and Komárek (1995) described the cell wall surface in empty coenobium of $P$. orientale viewed in light microscope as regularly granulated. The cell wall surface in an empty coenobium of $P$. orientale from the studied material viewed in LM was more or less regularly granulated (Figs 5-6), in SEM wrinkled with irregularly disposed granules (Fig. 8). Skuja (1937) also observed wrinkled cell wall surface, but with tiny depressions (ruguloso-scrobiculata). Nygaard (1977) noted that the cell wall surface is covered with pores disposed in oblique decussate series. There were $12-14$ series of pores per $10 \mu \mathrm{m}$, each pore was surrounded by minute light spots nearly hexagonally arranged. Several coenobia of $P$. kawraiskyi Schmidle showed by Sitkowska (1992) are identical with $P$. orientale. They only have single marginal cells slightly longer and conical, which are similar to marginal cells of P. kawraiskyi. However, the similarity suggests that the two species are closely related. The differences in the shape of marginal cell, the cell wall ornamentation and the length of the processes in $P$. orientale observed in both the studied material and the literature data could mean that the species is either morphologically variable or is an artificial species composed of several very similar species, or is a variety of $P$. kawraiskyi. Further studies on morphological variability of $P$. orientale are necessary.

\section{Ecology and distribution}

The species was recorded from cold and clear waters in distant regions: a mountain tarn in Turkey (Skuja 1937), a small arctic lake on the Bear Island (Lagerheim, according to Nygaard 1977), a mountain lake in the Andes (Grönblad, according to Nygaard 1977), a lake in Greenland (Nygaard 1977), small lakes in the Baltic region (Komárek nad Jankovská 2001) and subarctic oligotrophic lakes in Finland (Weckström et al. 2009). It was also noted in an unused pond, some fish ponds (one of them organically and minerally fertilized) in central Poland (Sitkowska 1992) and in eutrophic Lake Sumin, south-eastern Poland (Pasztaleniec and Poniewozik 2004). According to Komárek and Jankovská (2001) the species prefers clear and cold waters. $P$. orientale occurred sporadically in the studied lakes. The other Polish authors, Sitkowska (1992), Pasztaleniec and Poniewozik (2004), have not mentioned the frequency of its occurrence. Taxonomic and ecological studies in different types of water body are needed to describe its environmental requirements better. 

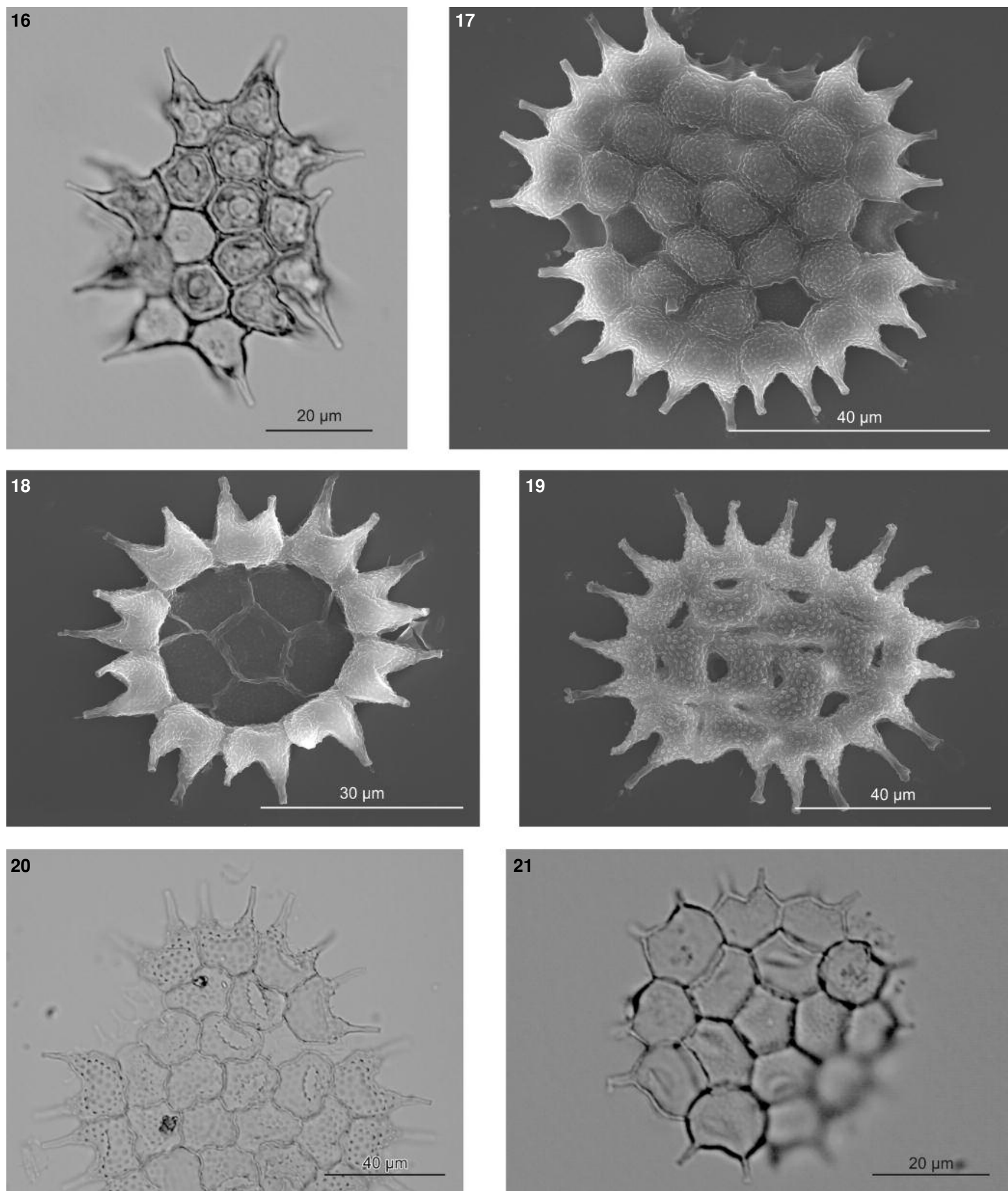

Figs 16-21. Fig. 16. . kawraiskyi Schmidle (LM). Fig. 17. P. boryanum (Turpin) Meneghini var. boryanum (SEM). Fig. 18. P. boryanum cf. var. cornutum (Raciborski) Sulek (SEM). Fig. 19. P. boryanum var. perforatum (Raciborski) Nitardy (SEM). Fig. 20. P. boryanum var. longicorne Reinsch (LM). Fig. 21. $P$. boryanum var. brevicorne A. Braun (LM).

\section{Pediastrum alternans Nygaard 1949}

(Figs 9-15)

Coenobia 82-127 $\mu \mathrm{m}$ diameter, circular or oval in outline, with very small perforations, 16-32-64-celled. Marginal cells 15-28 $\mu \mathrm{m}$ long, 12-22 $\mu \mathrm{m}$ wide, with two conical lobes, ended with long hyaline processes. Lobes situated out of the plane of coenobium. Every second lobe usually directed obliquely downwards, every second obliquely upwards. U-like incisions of marginal cells deeper than the sinus between the adjacent lobes of two neighboring cells. Inner cells 8-16 $\mu \mathrm{m}$ long, 11-26 $\mu \mathrm{m}$ wide, irregularly polygonal. Adjacent cell walls and lobes margin undulate. Cell wall surface finely or distinctly wrinkled, usually with several thickenings on each cell. 

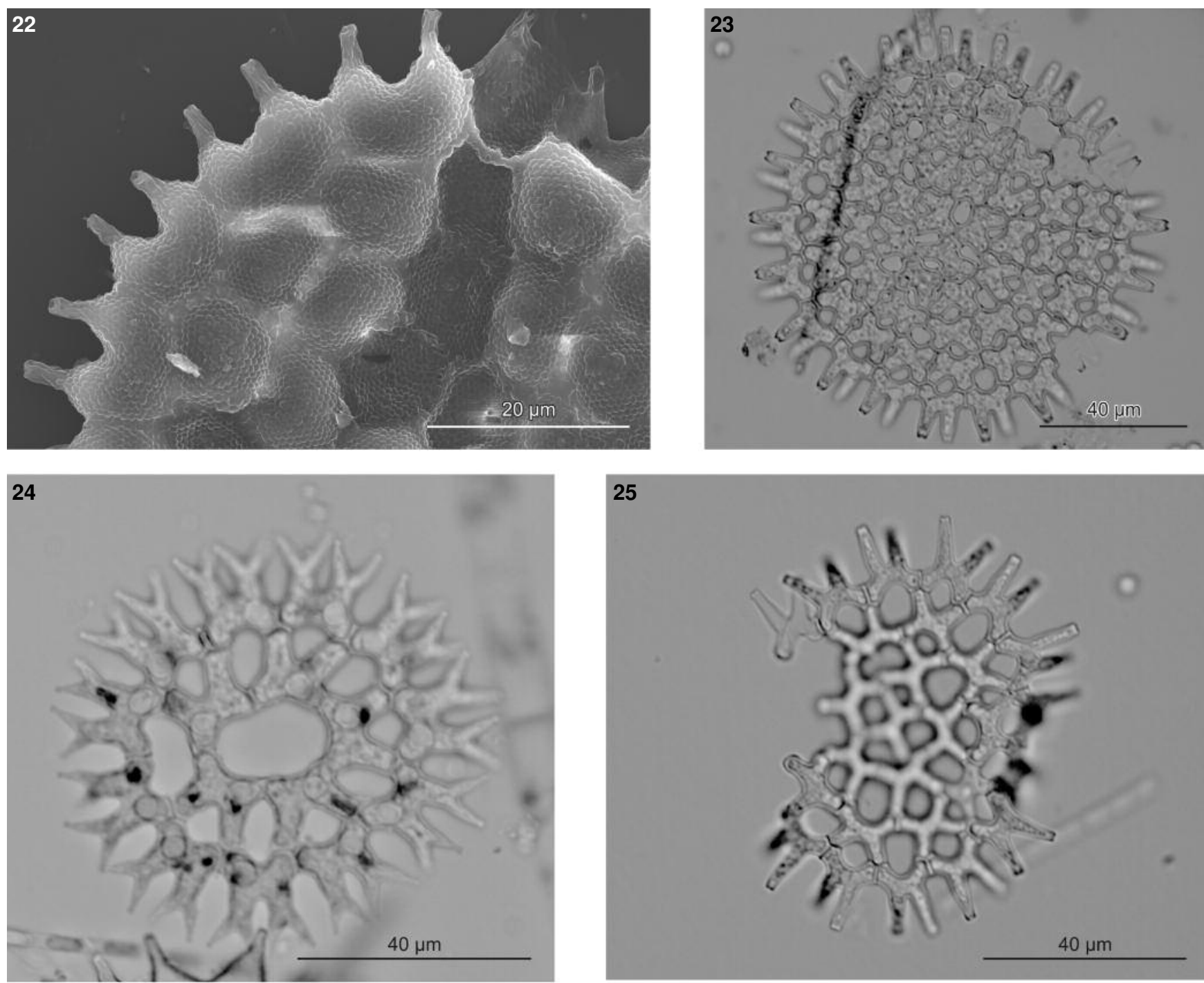

25
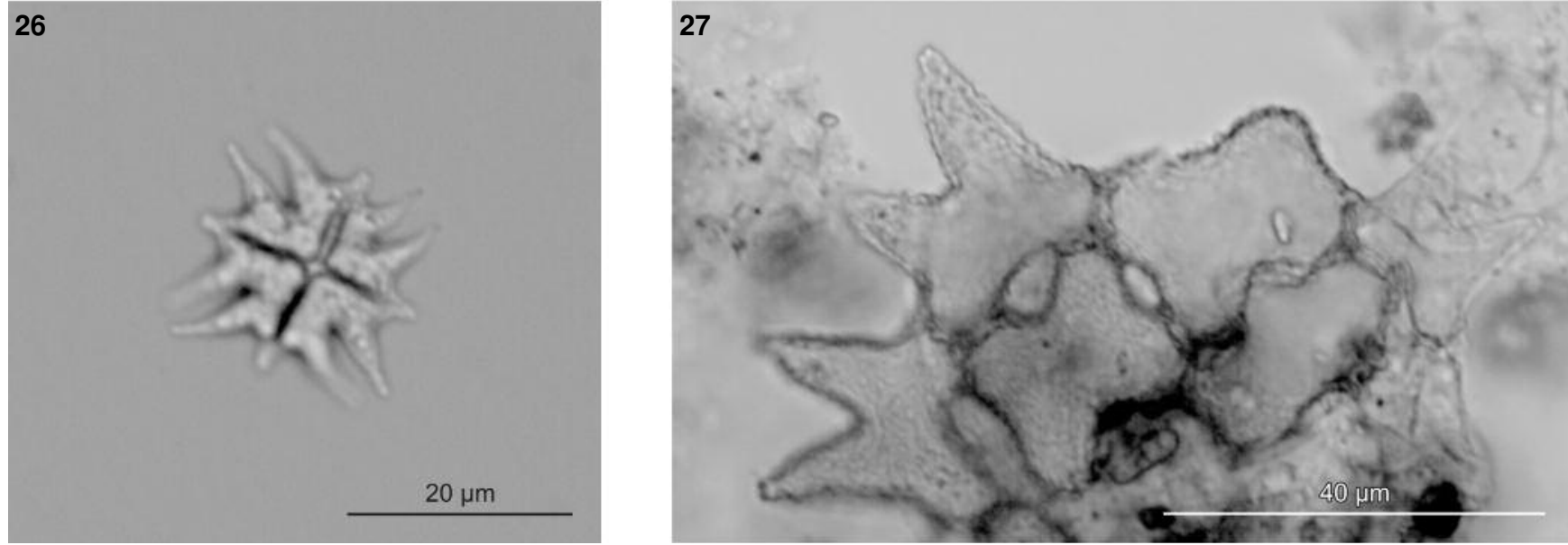

Figs 22-27. Fig. 22. . boryanum var. forcipatum (Corda) Chodat (SEM). Fig. 23. $P$. duplex Meyen var. duplex (LM). Fig. 24. $P$. biradiatum Meyen (LM). Fig. 25. . duplex var. gracillimum W. et G. S. West (LM). Fig. 26. P. tetras (Ehrenberg) Ralfs (LM). Fig. 27. P. duplex var. rugulosum Raciborski (LM).

\section{Taxonomic notes}

Nygaard (1949) described the cell wall surface as finely wrinkled and distinctly irregular (rugulis delicatissimis et irregularibus instructa). The surface in the studied material was sometimes very finely wrinkled, appearing regularly granulated (Fig. 14). In the studied material a new taxonomical feature was observed - single thickenings on the cell wall surface, well visible in mature cells viewed in LM at
2000× magnification under immersion (Fig. 12), in empty cells at lower magnifications (Fig. 13) and in SEM (Figs 14-15). The thickenings were more clearly visible than the cell wall wrinkles. They were apparently not a response to environmental conditions, because they were visible in the cultured material as well (Fig. 9). Such thickenings were not reported in Nygaard's (1949) account. This suggests that the coenobia from the coastal lakes are a variety of $P$. 
alternans. Nygaard (1949) either overlooked the thickenings or considered them an unimportant taxonomic feature. We could not find any information on such thickenings in the literature. The view shown by Pasztaleniec and Poniewozik (2004: Fig. 14) is too small to see the possible thickenings. An empty coenobium from fossil material (Komárek and Jankovská 2001: Pl. 19, C a) has got single granules, which are either similar thickenings or other unidentified particles lying on the coenobium.

\section{Ecology and distribution}

P. alternans has been recorded from Denmark (Nygaard 1949), southern Scandinavia (Komárek and Jankovská 2001) and south-eastern Poland (Pasztaleniec and Poniewozik 2004). It is better known from fossil materials: Wolin Island on the Baltic Sea coast of Poland (Latałowa and Borówka 2006), Czech Republic, south-eastern Poland (Komárek and Jankovská 2001), Denmark (Sarmaja-Korjonen et al. 2006) and Africa (Dupont and Wienelt 1996). Komárek and Jankovská (2001) assumed that the species requires large oligo- to mesotrophic lakes. However, it was also noted in eutrophic Lake Sumin in south-eastern Poland (Pasztaleniec and Poniewozik 2004) and in the studied eutrophic lakes. If the coenobia of $P$. alternans from Lake Sumin had got the thickenings they would belong, together with the coenobia from coastal lakes, to a separate variety preferring eutrophic water bodies. Detailed studies on phenotypes of $P$. alternans from different water bodies should be conducted in the future.

\section{DISCUSSION}

The studied material showed three species which appear to be especially rare in Poland, $P$. orientale, $P$. alternans and $P$. musterii, the last being the first record from central Europe. The phytoplankton of the most brackish lakes, Bukowo and Łebsko, and the less brackish Lake Jamno were dominated in summer by cyanobacteria and coccal green algae (Chlorophyceae, Chlorococcales). In Lake Gardno, apart from these two groups of algae, species of Aulacoseira Thwaites and Fragilaria Lyngbye (Bacillariophyceae) were frequently observed. The plankton of Lake Sarbsko consisted mainly of species of Fragilaria e.g. F. construens (Ehrenberg) Grunow, F . brevistriata Grunow in van Heurck and $F$. pinnata Ehrenberg. Strzelecki and Półtorak (1971), Picińska-Fałtynowicz (1997) observed massive occurrence of cyanobacteria in Lake Gardno. Burchardt and others (2003) noted a dominance of coccal green algae in Gardno and Łebsko, and none of the Pediastrum species was a dominant during their studies.

Pediastrum formed only a small proportion of the algal communities of these lakes: about several per cent in Jamno, Bukowo, Gardno, Łebsko, $<1 \%$ in Sarbsko. Within the genus, $P$. boryanum was the most frequent in all the five lakes; $P$. duplex the next most frequent in Gardno and $P$. kawraiskyi in Jamno. Strzelecki and Półtorak (1971) also noted $P$. boryanum to be the most frequent in Gardno, while Burchardt and others (2003) noted $P$. boryanum and $P$. kawraiskyi to be the most frequent in this lake; they also reported $P$. boryanum to be most frequent in Lake Lebsko.

In total, eight Pediastrum species (15 taxa) were noted in the phytoplankton during summer. Four species, $P$. borya- num, $P$. duplex, $P$. biradiatum and $P$. tetras, are very often found in Polish water bodies (Siemińska and Wołowski 2003). Based on taxonomic diversity rather than frequency within the community, all five lakes are favourable biotopes for the genus. A smilar taxonomic diversity has been recorded from eutrophic Lake Sumin (Pasztaleniec and Poniewozik 2004) and fish ponds (Sitkowska 1992). The highest number of species occurred in Łebsko (seven), the lowest in Jamno (four). Including varieties, the highest number of taxa occurred in Gardno (twelve), the lowest in Jamno and Bukowo (seven). P. kawraiskyi, P. boryanum var. boryanum and $P$. duplex var. duplex occurred in all five lakes. P. kawraiskyi (Strzelecki and Półtorak 1971; Picińska-Fałtynowicz 1997; Burchardt et al. 2003), P. boryanum var. boryanum (Strzelecki and Półtorak 1971; Picińska-Fałtynowicz 1997; Burchardt et al. 2003), P. boryanum var. longicorne (Burchardt et al. 2003), P. duplex var. duplex (Burchardt et al. 2003) and P. tetras (Strzelecki and Półtorak 1971; Picińska-Fałtynowicz 1997; Burchardt et al. 2003) were observed during both the recent and the past studies in lakes Gardno and Łebsko. Pediastrum integrum Nägeli (Strzelecki and Półtorak 1971), P. argentiniense Bourrelly et Tell in Tell (as P. duplex var. cohaerens Bohlin in Strzelecki and Półtorak 1971), P. simplex Meyen and $P$. longecornutum (Gutwiński) Comas (Burchardt et al. 2003) were observed during the past studies in Lake Gardno, but were not during our studies in this lake. Pediastrum boryanum var. cornutum (Burchardt et al. 2003) was observed during the past studies in Lake Łebsko, but were not during our studies in this lake. The three rare Pediastrum species, $P$. musterii, $P$. orientale, $P$. alternans, and $P$. boryanum var. perforatum, $P$. boryanum var. brevicorne, $P$. boryanum var. forcipatum, $P$. duplex var. gracillimum (if $P$. duplex var. clathratum is not its synonym in Strzelecki and Półtorak 1971, and $P$. duplex var. reticulatum is not its synonym in Burchardt et al. 2003), P. duplex var. rugulosum were recorded for the first time from the lakes Gardno and Łebsko.

\section{ACKNOWLEDGEMENTS}

The authors are grateful to Prof. Brian A. Whitton for valuable remarks on the manuscript and for suggestions on the English correction. The authors would like to thank M.A. Magdalena Jamroży for her help with translation of one original species description. This work was supported by the Polish Ministry of Science and Higher Education, grant no. N303 070534.

\section{LITERATURE CITED}

BORÓWKA R.K. 2002. Środowisko geograficzne. In: Przyroda Pomorza Zachodniego. Kaczanowska M. (ed.), Oficyna In Plus, Szczecin, pp. 6-105. (in Polish)

BURCHARDT L., MESSYASZ B., OWSIANNY P.M., PEŁECHATA A., STEFANIAK K. 2003. Chlorococcalean algae from four lakes in the Słowiński National Park (Northern Poland). Biologia, Bratislava 58 (4): 467-474.

COMAS GONZALEZ A., PEREZ BALIERO M.D. 2002. Chlamydophyceae (Chlorophyceae) from Merin lagoon (BrazilUruguay, South America) with special references to the family Botryococcaceae. Arch. Hydrobiol. Suppl., Algol. Studies 145: 49-65. 
DUPONT L.M., WEINELT M. 1996. Vegetation history of the savanna corridor between the Guinean and the Congolian rain forest during the last 150,000 years. Veget. Hist. Archaeobot. 5: 273-292.

FILIPIAK J., RACZYŃSKI M. 2000. Jeziora zachodniopomorskie (zarys faktografii). Akademia Rolnicza, Szczecin, pp. 1-256. (in Polish)

FLORCZYK H., GOŁOWIN S., SOLSKI A. 1976. Stan czystości wód jeziorowych Polski badanych w latach 1969-1972. Materiały badawcze, Ser. Gospodarka Wodna i Ochrona Wód 8: 1-58. (in Polish)

GRAHAM L.E., GRAHAM J.M., WILCOX L.W. 2009. Algae. Second edition. Pearson Benjamin Cummings, San Francisco, pp. 1-616.

IZAGUIRRE I., VINOCUR A. 1994. Algal assemblages from shallow lakes of the Salado River Basin (Argentina). Hydrobiologia 289: 57-64.

JANKOVSKÁ V., KOMÁREK J. 1995. Pediastrum orientale from subfossil layers. Folia Geobot. Phytotax. 30: 319-329.

KOMÁREK J., JANKOWSKÁ V. 2001. Review of the green algal genus Pediastrum: implication for pollen-analytical research. Bibl. Phycol. 108: 1-127.

KONDRACKI J. 1994. Geografia Polski. Mezoregiony fizycznogeograficzne. Polskie Wydawnictwo Naukowe, Warszawa, pp. 1-340. (in Polish)

LATAŁOWA M., BORÓWKA R.K. 2006. The Allerød/Younger Dryas transition in Wolin Island, northwest Poland, as reflected by pollen, macrofossils, and chemical content of an organic layer separating two aeolian series. Veget. Hist. Archaeobot. 15: 321-331.

NIELSEN H., SØRENSEN I. 1992. Taxonomy and stratigraphy of late-glacial Pediastrum taxa from Lysmosen, Denmark a preliminary study. Rev. Palaeobot. Palynol. 74: 55-75.

NYGAARD G. 1949. Hydrobiological Studies on some Danish ponds and lakes. Part II: The quotient hypothesis and some new or little known phytoplankton organisms. Kongel. Danske Vidensk. Selsk. Biol. Skr. 7 (1): 1-293.

NYGAARD G. 1977. New or interesting plankton algae with a contribution on their ecology. Kongel. Danske Vidensk. Selsk. Biol. Skr. 21 (1): 1-107.
PARRA O.O. 1979. Revision der Gattung Pediastrum Meyen (Chlorophyta). Bibl. Phycol. 48: 1-186.

PASZTALENIEC A., PONIEWOZIK M. 2004. Pediastrum species (Hydrodictyaceae, Sphaeropleales) in phytoplankton of Sumin Lake (Łęczna-Włodawa Lakeland). Acta Soc. Bot. Pol. 73 (1): 39-46.

PICIŃSKA-FAŁTYNOWICZ J. 1997. Glony. In: Przyroda Słowińskiego Parku Narodowego. Piotrowska H. (ed.), Bogucki Wydawnictwo Naukowe, Poznań-Gdańsk, pp. 143-156. (in Polish)

SARMAJA-KORJONEN K., SEPPÄNEN A., BENNIKE O. 2006. Pediastrum algae from the classic late glacial Bølling Sø site, Denmark: Response of aquatic biota to climate change. Rev. Palaeobot. Palynol. 138: 95-107.

SIEMIŃSKA J., WOŁOWSKI K. 2003. Catalogue of prokaryotic and eukaryotic algae noted in Poland. W. Szafer Institute of Botany, Polish Academy of Sciences, Kraków, pp. 1-255.

SITKOWSKA M. 1992. Taksony rodzaju Pediastrum Meyen występujące w stawach Łodzi i okolicy. Acta Univ. Lodz., Folia bot. 9: 47-104. (in Polish)

SKUJA H. 1937. Süßwasseralgen aus Griechenland und Kleinasien. Hedwigia 77: 15-70.

STARMACH K. 1963. Rośliny słodkowodne. Wstęp ogólny i zarys metod badania. Polskie Wydawnictwo Naukowe, Warszawa, pp. 1-272. (in Polish)

STARMACH K. 1969. Wody śródlądowe. Zarys hydrobiologii. Uniwersytet Jagielloński, Kraków, pp. 1-188. (in Polish)

STRZELECKI J., PÓŁTORAK T. 1971. Plankton przymorskiego jeziora Gardno w okresie letnim. Acta hydrobiol. 13 (3): 269-294. (in Polish)

TELL G., Mataloni G. 1990. Systematic studies on the Pediastrum kawraiskyi-musterii-patagonicum complex (Chlorophyta): Two new species and morphological variations in two $\mathrm{Pa}$ tagonian lakes (Argentina). Nova Hedwigia 50 (1-2): 159-180.

WECKSTRÖM K., WECKSTRÖM J., YLINIEMI L.-M. 2009. The ecology of Pediastrum (Chlorophyceae) in subarctic lakes and their potential as paleobioindicators. J. Paleolimnol. published online: 07 February 2009. 